\title{
Technological quality of grains of common beans selected genotypes from the carioca group
}

\section{Qualidade tecnológica de grãos de genótipos selecionados de feijão-comum do grupo carioca}

\author{
Marina Borges de Oliveira Silva ${ }^{1 *}$; Abner José de Carvalho²; José Eustáquio de \\ Souza Carneiro ${ }^{3}$; Ignacio Aspiazú ${ }^{2}$; Érika Endo Alves; Andréia Márcia Santos de \\ Souza David ${ }^{2}$; Orlando Gonçalves Brito ${ }^{5}$; Pablo Fernando Santos Alves ${ }^{1}$
}

\begin{abstract}
Common bean variety improvement programs focus on productivity increase as their main goal. However, some characteristics related to technological quality must also be analyzed in order to assure that new recommended cultivars satisfy key commercial standards, related to consumer acceptance. This study evaluated the technological quality of seeds from different 'carioca' bean genotypes. We tested seeds from 25 bean genotypes, selected by the State Consortium for Research on Common Bean Improvement (including EMBRAPA, UFLA, UFV and EPAMIG) for the VCU assay of the carioca variety, including 21 new lines and 4 commercial cultivars, used as controls. The experiment was arranged in a randomized complete block design with three replications. We assessed the following traits: seed shape, seed constriction, 1000-seed weight, percentage of hard seeds, soluble solids content, cooking time, seed coat percentage, and hydration capacity. According to our results, the cultivars that met the commercial standards for seed shape and constriction were EMB14, CNFC 10432, CNFC 10408, EMB4, P-18163, Pérola and BRSMG Madrepérola. Genotypes MAIV-18259, VC-20, VC-23, RCII-219, CVIII-2, EMB4, MAIV-15204, CVIII-5, and BRSMG Majestoso had 1000-seed weight within carioca bean commercial standards (a minimum of $23 \mathrm{~g}$ per 100 seeds). Most genotypes had no hard seeds. Lines CNFC 10408, MAIV-18259 and P-18163 had the highest soluble solids content. Twenty genotypes had cooking times below the maximum required by commercial standard, with lines EMB9, EMB4, MAIV-18524, CNFC 11965, VC-17, and CNFC 10432 having the shortest cooking time. Lines CNFC 11965, EMB4, EMB14, and CNFC 10432 also had the shortest time to soaking.
\end{abstract}

Key words: Cooking. Soaking. VCU assay. Phaseolus vulgaris L.

\section{Resumo}

O aumento de produtividade é o principal objetivo dos programas de melhoramento de feijão-comum. Contudo, algumas características relacionadas à qualidade tecnológica devem ser analisadas para assegurar que a recomendação de novas cultivares considere também aspectos comerciais importantes

\footnotetext{
${ }^{1}$ Discentes do Curso de Doutorado do Programa de Pós-graduação em Produção Vegetal no Semiárido, Departamento de Ciências Agrárias, Universidade Estadual de Montes Claros, UNIMONTES, Campus Janaúba, MG, Brasil. E-mail: mariunim@yahoo. com.br; agrotecnico10@yahoo.com.br

${ }^{2}$ Profs., Departamento de Ciências Agrárias, UNIMONTES, Campus Janaúba, MG, Brasil. E-mail: abjocar@yahoo.com.br; aspiazu@gmail.com; andreiamssdavid@yahoo.com.br

${ }^{3}$ Prof., Departamento de Fitotecnia, Universidade Federal de Viçosa, UFV, Viçosa, MG, Brasil. E-mail: eustaquiocarneiro@yahoo. com.br

${ }^{4}$ Prof ${ }^{a}$, Instituto de Ciências Agrárias, Universidade Federal de Minas Gerais, UFMG, Campus Montes Claros, MG, Brasil. E-mail: erikaendobr@yahoo.com.br

${ }^{5}$ Discente do Curso de Doutorado do Programa de Pós-Graduação em Produção Vegetal, Universidade Federal dos Vales Jequitinhonha e Mucuri, UFVJM, Diamantina, MG, Brasil. E-mail: orlandocefet@yahoo.com.br

* Author for correspondence
} 
para a aceitação do consumidor. Assim, o objetivo deste trabalho foi avaliar a qualidade tecnológica de grãos de genótipos de feijão-comum do grupo comercial carioca. Foram utilizados grãos de 25 genótipos selecionados pelo convênio Estadual de pesquisa em melhoramento de feijão-comum (EMBRAPA, UFLA, UFV e EPAMIG) para compor o ensaio de VCU do grupo comercial carioca, sendo 21 novas linhagens e 4 cultivares comerciais usadas como testemunha. $\mathrm{O}$ delineamento experimental utilizado foi o de blocos casualizados, com três repetições. As características avaliadas foram à forma e o grau de achatamento dos grãos, a massa de mil grãos, a porcentagem de grãos duros, o teor de sólidos solúveis, o tempo de cocção, a porcentagem de casca e a capacidade de hidratação. Os resultados obtidos permitiram concluir que os genótipos que apresentam forma e grau de achatamento de acordo com o padrão comercial são EMB14, CNFC 10432, CNFC 10408, EMB4, P-18163, Pérola e BRSMG Madrepérola. Os genótipos MAIV-18259, VC-20, VC-23, RCII-219, CVIII-2, EMB4, MAIV-15204, CVIII-5, e BRSMG Majestoso apresentam massa de mil grãos compatível com o padrão comercial para grãos do tipo carioca, que é no mínimo $23 \mathrm{~g}$ por cem grãos. A maioria dos genótipos avaliados não apresenta grãos duros. As linhagens CNFC 10408, MAIV-18259 e P-18163 apresentam os maiores teores de sólidos solúveis. Vinte dos genótipos avaliados apresentam tempo de cocção inferior ao exigido como padrão comercial, sendo que as linhagens EMB 9, EMB 4, MAIV-18524, CNFC 11965, VC-17 e CNFC 10432 são as que apresentam menores tempos de cozimento. As linhagens CNFC 11965, EMB4, EMB14 e CNFC 10432 despendem menor tempo para hidratação dos grãos.

Palavras-chave: Cocção. Embebição. Ensaio de VCU. Phaseolus vulgaris L.

\section{Introduction}

The common bean (Phaseolus vulgaris L.) is a traditional food in Brazil and is among the 10 most cultivated crops in the country with a total production 2,564,790 metric tons harvested from 1,895,267 ha in 2013 for an average yield of $1,353 \mathrm{~kg} \mathrm{ha}^{-1}$, one of the largest in recent years (EMBRAPA, 2014). Different types of beans from different market classes are grown in Brazil, of which 'carioca' is the most widely consumed and traded market class, accounting for approximately $70 \%$ of total beans consumed (MELO et al., 2012). Thus, the main bean breeding programs in Brazil have given greater emphasis to varieties in this market class.

Increasing crop yield or maintaining productivity at satisfactory levels with the addition of one or more traits of interest has been the primary objective of breeding programs (MELO et al., 2005), but the mechanization of agriculture and the agribusiness model have created new demands on breeding programs, including the technological quality of the grains traded (COSTA et al., 2015). Accordingly, the testing of technological quality characteristics such as average cooking time, total solids content, percentage of whole seeds, pre- and post-cooking water-holding capacity, and protein content is required for inclusion of bean genotypes into the National Cultivar Registry/Ministry of Agriculture, Livestock and Food Supply (BRASIL, 2006). Additionally, market acceptance of new cultivars depends on other traits, including seed shape and seed constriction, seed coat percentage, percentage of hard seeds, and soaking capacity - which may or may not correlate with cooking time (COSTA et al., 2001; RIBEIRO et al., 2003; LEMOS et al., 2004; ZIMMERMANN et al., 2009; BORDIN et al., 2010; OLIVEIRA et al., 2012, 2013).

Pre-registration test and merit assessment assays (Value for Cultivation and Use, VCU assays), required under Brazilian legislation for registration of new cultivars and lines, are conducted in a variety of sites and growing seasons, in order to evaluate agronomic performance of the genotypes. Assessment of technological and commercial characteristics is an important aspect in the selection and recommendation of new cultivars, in order to maximize consumer and farmer acceptance. Thus, this study evaluated the technological quality of seeds from different 'carioca' bean genotypes. 


\section{Materials and Methods}

The study was conducted in the Bean Breeding Laboratory at Universidade Federal de Viçosa (UFV), Viçosa, Minas Gerais, and in the Animal and Plant Products Technology Laboratory, Department of Agricultural Sciences at Universidade Estadual de Montes Claros (UNIMONTES), Janaúba, Minas Gerais. Seeds from 21 'carioca' bean group genotypes selected for VCU trials were evaluated, with four commercial cultivars (BRSMG Talismã, BRSMG Madrepérola, BRSMG Majestoso, and Pérola) used as controls. The experiment was arranged in a randomized complete block design with three replications. Seeds were sown during the 2012 winter harvest in Coimbra, Minas Gerais, Brazil.

The following technological characteristics were evaluated: seed shape (length-to-width ratio, $\mathrm{mm}$ ), seed constriction (height-to-width ratio, $\mathrm{mm}$ ), 1000 -seed weight $(\mathrm{g})$, percentage of hard seeds (\%), soluble solids content ( ${ }^{\circ}$ Brix), cooking time (min), seed coat percentage (\%), and water-holding capacity $(\%)$.

For seed shape and constriction measurements, 20 seeds were randomly selected from each lot of the 25 genotypes. Seed length, width, and thickness of each seed were measured with a Vernier caliper to determine seed shape and seed constriction. Seed shape was determined from the seed length-towidth ratio and classified as spherical (1.16-1.42), elliptical (1.42-1.65), short-oblong reniform (1.66$1.85)$, moderate-oblong reniform (1.86-2.0), and long-oblong reniform $(>2.0)$. Seed constriction was determined from the seed height-to-width ratio and classified as flat $(<0.69)$, semi-round (0.70-0.79), and round $(>0.80)$ according to Puerta Romero (1961).

The weight, in grams, of three randomly selected samples of 1000 seeds per lot (1000-seed weight) was recorded with precision balance and corrected for moisture content (13\%).
The percentage of hard seeds was estimated by soaking 100 randomly selected seeds from each lot in $200 \mathrm{~mL}$ of distilled water at room temperature $\left(25^{\circ} \mathrm{C}\right)$ for $16 \mathrm{~h}$; unsoaked seeds were identified by seed coat wrinkling.

Hydration capacity was determined using a method adapted from Garcia-Vela and Stanley (1989), based on the difference in seed mass before and after soaking. Briefly, $8 \mathrm{~g}$ of seeds from each lot were soaked in a $400 \mathrm{~mL}$ plastic beaker with 100 $\mathrm{mL}$ of distilled water for $24 \mathrm{~h}$. Seeds were drained for 1 min every hour and weighed in the first four hours, and drained and weighed after 8 and $24 \mathrm{~h}$. Hydration capacity was determined by the formula:

$$
\mathrm{HC}=\left[\left(\mathrm{W}_{\mathrm{f}}-\mathrm{W}_{\mathrm{i}}\right) / \mathrm{W}_{\mathrm{i}}\right] \mathrm{x} 100
$$

where, $\mathrm{HC}=$ hydration capacity $(\%) ; \mathrm{W}_{\mathrm{i}}=$ initial weight of sample $(\mathrm{g})$; and $\mathrm{W}_{\mathrm{f}}=$ final weight of sample $(\mathrm{g})$.

The hydration capacity experiment was arranged in a $25 \times 7$ factorial design with three replications of 25 genotypes and seven soaking times $(0,1,2,3,4$, 8 , and $24 \mathrm{~h}$ ).

The soluble-solids content in the broth was determined by soaking $8 \mathrm{~g}$ of seeds per lot in 100 $\mathrm{mL}$ of distilled water for $24 \mathrm{~h}$. After soaking, the seeds were placed into a $250 \mathrm{~mL}$ beaker with 100 $\mathrm{mL}$ of water and cooked in a boiling water bath until the seeds softened, ascertained by piercing the cooked beans with a kitchen fork. Next, the broth was cooled down and the soluble solids content in ${ }^{\circ}$ Brix was measured on a $2 \mathrm{~mL}$ broth aliquot using a Reichert ${ }^{\mathrm{TM}} \mathrm{AR} 200^{\mathrm{TM}}$ handheld digital refractometer.

Seed coat percentage was determined from five cooked seeds from the soluble solids analysis. Seed coats and cotyledons were separated, placed in paper bags, and oven-dried at $105{ }^{\circ} \mathrm{C}$ to constant weight. Next, seed coats and cotyledons were weighed in a precision balance and seed coat percentage was determined by the formula:

$\%$ seed coat $=[($ seed coat weight $(\mathrm{g})+$ cotyledon weight $(\mathrm{g})) \times 100]$ 
The cooking time of each genotype was determined on two 25-seed samples from each lot, pre-soaked in $50 \mathrm{~mL}$ of distilled water for $16 \mathrm{~h}$, using a modified Mattson cooker with $2590 \mathrm{~g}$ plungers and $1 \mathrm{~mm}$-tip probes, following the method of Proctor and Watts (1987). The cooker was placed in a $2 \mathrm{~L}$ beaker under heat with boiling distilled water. The optimum cooking time in min was recorded as the time it took for the thirteenth plunger to pierce the seeds.
The data were analyzed using analysis of variance (ANOVA). Genotype means for 1000-seed weight, $\%$ hard seeds, $\%$ soluble solids, seed coat percentage, and cooking time were compared using the Scott-Knott test $(\mathrm{p}<0.05)$. Hydration capacity was analyzed using regression analysis. The effect of soaking time on hydration capacity was determined using the sigmoid function $\mathrm{y}=\mathrm{a} /\left(1+\exp \left(-\left(\mathrm{x}-\mathrm{x}_{0}\right) / \mathrm{b}\right)\right)$ (Figure 1), where $a$ represents the maximum water uptake, $b$ represents the slope of the water uptake response, and $x_{0}$ represents the time to $50 \%$ soaking of common bean seeds.

Figure 1. Sigmoidal model representing the effect of soaking time on hydration capacity in seeds from 25 carioca bean genotyes.

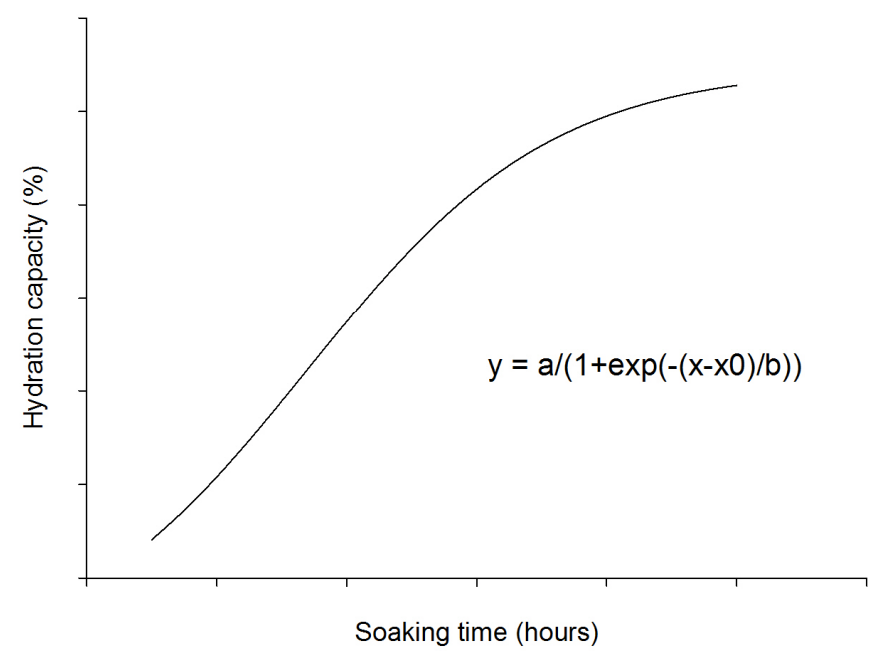

\section{Results and Discussion}

Seed shape of most genotypes was elliptical, except for cultivar BRSMG Majestoso and line VC-22, which had spherical seeds, and line EMB9, which had short-oblong reniform seeds (Table 1). In Brazil, elliptical grains are preferred over spherical and reniform ones, which do not conform to the local commercial standard (CARBONELL et al., 2010).

Seeds from 16 of the 25 carioca bean genotypes were classified as flat. Seeds from genotypes CNFC 10432, CNFC 10408, EMB9, EMB4, P-18163,
Pérola, BRSMG Madrepérola, and VC-19 were semi-round, whereas seeds from line EMB14 were round (Table 1). The consumer preference is for semi-round to round and elliptical grains (CARBONELL et al., 2010).

The 1000-seed weight ranged from 191.31$263.87 \mathrm{~g}$, with line MAIV-18259 having the highest value, followed by lines VC-20 and VC-23 (Table 2). Only genotypes MAIV-18259, VC-20, VC23, RCII-219, CVIII-2, EMB4, MAIV-15204, CVIII-5, and BRSMG Majestoso complied with the commercial seed weight standard for carioca 
beans, which is a minimum $230 \mathrm{~g}$ per 1000 seeds (RAMALHO; ABREU, 2006). Abreu et al. (2011) reported that seeds from cultivar BRSMG Madrepérola had a mean 100-seed weight of $25.4 \mathrm{~g}$ and darkened more slowly than other carioca bean cultivars. Pereira et al. (2013) found 100-seed weight of $22.2 \mathrm{~g}$ for cultivar Pérola. Additionally, Perina et al. (2010) showed that genotypes with high 1000seed weights had greater volumetric expansion and yield after cooking, which is a trait required by both the consumer market and the wholesaler/retailer.

Table 1. Mean length-to-width ratio (LWR) and height-to-width ratio (HWR) and seed shape and seed constriction classification in seeds from 25 carioca bean genotypes grown in the 2012 winter harvest in Coimbra, Minas Gerais, Brazil.

\begin{tabular}{lcccc}
\hline GENOTYPE & \multicolumn{2}{c}{ Seed shape } & \multicolumn{2}{c}{ Seed constriction } \\
\cline { 2 - 5 } MAIV-18259 & LWR (mm) & Classification & HWR $(\mathbf{m m})$ & Classification \\
RCII-219 & 1.49 & elliptical & 0.65 & flat \\
CVIII-2 & 1.48 & elliptical & 0.65 & flat \\
MAIV-15204 & 1.50 & elliptical & 0.66 & flat \\
MAIV-18524 & 1.45 & elliptical & 0.68 & flat \\
EMB14 & 1.49 & elliptical & 0.63 & flat \\
CNFC 10432 & 1.51 & elliptical & 0.86 & round \\
CNFC 11965 & 1.49 & elliptical & 0.78 & semi-round \\
VC-17 & 1.61 & elliptical & 0.69 & flat \\
CNFC 10763 & 1.49 & elliptical & 0.68 & flat \\
CVIII-5 & 1.52 & elliptical & 0.69 & flat \\
CNFC 10408 & 1.50 & elliptical & 0.69 & flat \\
EMB9 & 1.43 & elliptical & 0.70 & semi-round \\
EMB4 & 1.73 & short-oblong reniform & 0.73 & semi-round \\
P-18163 & 1.52 & elliptical & 0.75 & semi-round \\
VC-23 & 1.56 & elliptical & 0.75 & semi-round \\
BRSMG TALISMÃ & 1.49 & elliptical & 0.66 & flat \\
PÉROLA & 1.50 & elliptical & 0.69 & flat \\
BRSMG MADREPÉROLA & 1.48 & elliptical & 0.70 & semi-round \\
BRSMG MAJESTOSO & 1.51 & elliptical & 0.74 & semi-round \\
VC-21 & 1.36 & spherical & 0.63 & flat \\
VC-22 & 1.49 & elliptical & 0.67 & flat \\
VC-20 & 1.36 & spherical & 0.58 & flat \\
VC-19 & 1.56 & elliptical & 0.64 & flat \\
VC-18 & 1.47 & elliptical & 0.70 & semi-round \\
\hline SEd & 1.58 & elliptical & 0.68 & flat \\
\hline
\end{tabular}

Seed shape and seed constriction classification according to Puerta Romero (1961).

We detected hard seeds only in genotypes MAIV18259, VC-23, VC-18, CVIII-5, and BRSMG Madrepérola (Table 2). Hard seeds are undesirable because they increase cooking time (BERTOLDO et al., 2009; RAMÍREZ-CÁRDENAS et al., 2008) and reduce commercial acceptance. The presence of hard seeds is related to the "hard-tocook" (HTC) phenomenon (NASAR-ABBAS et al., 2008; RIBEIRO et al., 2007), which describes the condition in which beans take longer to soften during cooking or do not soften even after prolonged cooking in boiling water.

Soluble solids was highest in line CNFC 10408 (13.63 ${ }^{\circ}$ Brix), followed by MAIV-18259 (11.27 ${ }^{\circ}$ Brix), and P-18163 (9.93 ${ }^{\circ}$ Brix) (Table 2). Soluble 
solid content in these three genotypes equaled or exceeded those found in carioca cultivars currently in the market. For example, Abreu et al. (2007) reported soluble solids of $8.9^{\circ}$ Brix, $10.6^{\circ}$ Brix, and $11{ }^{\circ}$ Brix by for cultivars BRSMG Majestoso, Pérola, and BRSMG Talismã, respectively. However, in the current study, genotypes Pérola, CVIII-2, MAIV-18524, BRSMG Talismã, VC-22,
BRSMG Majestoso, EMB14, VC-21, and BRSMG Madrepérola had the lowest soluble solids, ranging from 1.63-2.57 ${ }^{\circ}$ Brix (Table 2). Soluble solids content is an important trait in determining broth quality of cooked beans and consumer research indicates a preference for viscous broth after cooking, which should favor the new varieties with similar or higher soluble solid content compared to current cultivars (BASSINELLO et al., 2003).

Table 2. Mean 1000-seed weight, percentage of hard seeds (HS), soluble solids, cooking time, and seed coat percentage in seeds from 25 carioca bean genotypes grown in the 2012 winter harvest in Coimbra, Minas Gerais, Brazil.

\begin{tabular}{lccccc}
\hline GENOTYPE & $\begin{array}{c}\text { 1000-seed weight } \\
(\mathbf{g})\end{array}$ & $\begin{array}{c}\text { HS } \\
(\%)\end{array}$ & $\begin{array}{c}\text { Soluble solids } \\
\left({ }^{\circ} \mathbf{B r i x}\right)\end{array}$ & $\begin{array}{c}\text { Cooking time } \\
(\mathbf{m i n})\end{array}$ & $\begin{array}{c}\text { Seed coat } \\
(\%)\end{array}$ \\
\hline EMB9 & $228.79 \mathrm{~d}$ & $0.00 \mathrm{~d}$ & $5.57 \mathrm{~g}$ & $22.7 \mathrm{f}$ & $11.45 \mathrm{a}$ \\
MAIV-18259 & $263.87 \mathrm{a}$ & $2.00 \mathrm{a}$ & $11.27 \mathrm{~b}$ & $29.4 \mathrm{~d}$ & $6.09 \mathrm{c}$ \\
VC-20 & $249.78 \mathrm{~b}$ & $0.00 \mathrm{~d}$ & $5.27 \mathrm{~g}$ & $31.0 \mathrm{c}$ & $9.32 \mathrm{~b}$ \\
VC-23 & $253.97 \mathrm{~b}$ & $2.00 \mathrm{a}$ & $6.63 \mathrm{~g}$ & $28.5 \mathrm{~d}$ & $10.94 \mathrm{a}$ \\
PÉROLA & $223.87 \mathrm{e}$ & $0.00 \mathrm{~d}$ & $1.90 \mathrm{i}$ & $25.7 \mathrm{e}$ & $9.20 \mathrm{~b}$ \\
RCII-219 & $240.88 \mathrm{c}$ & $0.00 \mathrm{~d}$ & $7.20 \mathrm{e}$ & $26.7 \mathrm{e}$ & $5.50 \mathrm{c}$ \\
CVIII-2 & $241.96 \mathrm{c}$ & $0.00 \mathrm{~d}$ & $2.57 \mathrm{i}$ & $28.8 \mathrm{~d}$ & $6.46 \mathrm{c}$ \\
VC-18 & $223.72 \mathrm{e}$ & $0.66 \mathrm{c}$ & $7.47 \mathrm{e}$ & $27.4 \mathrm{e}$ & $10.08 \mathrm{~b}$ \\
EMB4 & $232.17 \mathrm{~d}$ & $0.00 \mathrm{~d}$ & $7.47 \mathrm{e}$ & $23.2 \mathrm{f}$ & $11.02 \mathrm{a}$ \\
MAIV-18524 & $224.60 \mathrm{e}$ & $0.00 \mathrm{~d}$ & $2.30 \mathrm{i}$ & $24.2 \mathrm{f}$ & $6.58 \mathrm{c}$ \\
BRSMG TALISMÃ & $212.87 \mathrm{~g}$ & $0.00 \mathrm{~d}$ & $2.03 \mathrm{i}$ & $25.9 \mathrm{e}$ & $11.78 \mathrm{a}$ \\
CNFC 11965 & $191.31 \mathrm{~h}$ & $0.00 \mathrm{~d}$ & $4.57 \mathrm{~h}$ & $24.7 \mathrm{f}$ & $4.82 \mathrm{c}$ \\
VC-22 & $216.66 \mathrm{f}$ & $0.00 \mathrm{~d}$ & $2.27 \mathrm{i}$ & $27.7 \mathrm{e}$ & $7.04 \mathrm{c}$ \\
BRSMG MAJESTOSO & $234.26 \mathrm{~d}$ & $0.00 \mathrm{~d}$ & $2.27 \mathrm{i}$ & $29.2 \mathrm{~d}$ & $9.24 \mathrm{~b}$ \\
EMB14 & $222.84 \mathrm{e}$ & $0.00 \mathrm{~d}$ & $2.47 \mathrm{i}$ & $25.4 \mathrm{e}$ & $9.39 \mathrm{~b}$ \\
CNFC 10763 & $216.88 \mathrm{f}$ & $0.00 \mathrm{~d}$ & $3.97 \mathrm{~h}$ & $26.0 \mathrm{e}$ & $8.35 \mathrm{~b}$ \\
MAIV-15204 & $236.02 \mathrm{~d}$ & $0.00 \mathrm{~d}$ & $9.07 \mathrm{~d}$ & $26.6 \mathrm{e}$ & $4.66 \mathrm{c}$ \\
VC-21 & $206.34 \mathrm{~g}$ & $0.00 \mathrm{~d}$ & $2.10 \mathrm{i}$ & $25.9 \mathrm{e}$ & $13.08 \mathrm{a}$ \\
CNFC 10408 & $214.73 \mathrm{~g}$ & $0.00 \mathrm{~d}$ & $13.63 \mathrm{a}$ & $36.0 \mathrm{a}$ & $12.28 \mathrm{a}$ \\
P-18163 & $212.28 \mathrm{~g}$ & $0.00 \mathrm{~d}$ & $9.93 \mathrm{c}$ & $31.6 \mathrm{c}$ & $10.53 \mathrm{a}$ \\
VC-17 & $212.12 \mathrm{~g}$ & $0.00 \mathrm{~d}$ & $6.40 \mathrm{~g}$ & $23.6 \mathrm{f}$ & $9.75 \mathrm{~b}$ \\
CVIII-5 & $231.71 \mathrm{~d}$ & $1.00 \mathrm{~b}$ & $8.27 \mathrm{~d}$ & $34.0 \mathrm{~b}$ & $9.47 \mathrm{~b}$ \\
VC-19 & $211.14 \mathrm{~g}$ & $0.00 \mathrm{~d}$ & $3.90 \mathrm{~h}$ & $30.6 \mathrm{c}$ & $10.74 \mathrm{a}$ \\
BRSMG MADREPÉROLA & $225.84 \mathrm{e}$ & $2.00 \mathrm{a}$ & $1.63 \mathrm{i}$ & $29.3 \mathrm{~d}$ & $11.07 \mathrm{a}$ \\
CNFC 10432 & $210.30 \mathrm{~g}$ & $0.00 \mathrm{~d}$ & $6.73 \mathrm{~g}$ & $23.4 \mathrm{f}$ & $7.01 \mathrm{c}$ \\
\hline CV (\%) & 1.44 & 7.06 & 10.03 & 2.78 & 12.91 \\
\hline
\end{tabular}

Means followed by different letters in a column are significantly different (Scott-Knott test, $\mathrm{p}<0.05$ ).

$\mathrm{CV}=$ coefficient of variation

Lines EMB 9, EMB 4, MAIV-18524, CNFC 11965, VC-17, and CNFC 10432 had the shortest cooking time, ranging from 22.7-24.7 min and were superior to control cultivars, whose cooking times ranged from 25.7-29.3 min (Table 2). Similarly, Abreu et al. (2007) reported cooking times between 27 and $31 \mathrm{~min}$ for cultivars BRMG Majestoso, Pérola, and BRSMG Talismã. Cooking time less 
than $30 \mathrm{~min}$ is desirable for bean cultivars, because it means saving energy and resources. In addition, beans that require extremely long cooking times to become palatable may have inferior nutritional qualities in terms of protein, vitamin, and mineral contents (PUJOLA et al., 2007; RAMÍREZCÁRDENAS et al., 2008). Finally, the development of quick-cooking bean cultivars meets the needs of consumers, who have limited time available for cooking and wish to reduce the energy (and costs) required in cooking (OLIVEIRA, 2013).

Seed coat percentage was highest in genotypes EMB9, VC-23, EMB4, BRSMG Talismã, VC21, CNFC 10408, P-18163, VC-19, and BRSMG
Madrepérola, whereas lines MAIV-18259, RCII219, CVIII-2, MAIV-18524, CNFC 11965, VC22, MAIV-15204, and CNFC10432 had the lowest seed coat percentage (Table 2). A low seed coat percentage is a desirable trait, as a high \% seed coat affects the perceived stimulus of chewing and reduces consumer acceptance (OLIVEIRA et al., 2013).

Hydration capacity (HC) values were not significantly different across genotypes at time 0 (Table 3) and represent the initial moisture content of dry beans. Thus, moisture content was similar across genotypes and did not affect the HC experiment.

Table 3. Sliced hydration capacity (\%) at different soaking times in seeds from 25 carioca bean genotypes grown in the 2012 winter harvest in Coimbra, Minas Gerais, Brazil.

\begin{tabular}{|c|c|c|c|c|c|c|c|}
\hline \multirow{2}{*}{ GENOTYPE } & \multicolumn{7}{|c|}{ SOAKING TIME (hours) } \\
\hline & $\mathbf{0}$ & 1 & 2 & 3 & 4 & 8 & 24 \\
\hline CNFC 10408 & $11.98 \mathrm{a}$ & $18.70 \mathrm{~d}$ & $25.17 \mathrm{~d}$ & $41.11 \mathrm{e}$ & $55.68 \mathrm{~d}$ & $107.45 \mathrm{c}$ & $133.13 \mathrm{~b}$ \\
\hline CNFC 10432 & $11.09 \mathrm{a}$ & $59.93 \mathrm{~b}$ & $75.36 \mathrm{~b}$ & $93.09 \mathrm{~b}$ & $104.69 \mathrm{~b}$ & $127.81 \mathrm{a}$ & $133.17 \mathrm{~b}$ \\
\hline CNFC 10763 & $10.98 \mathrm{a}$ & $27.38 \mathrm{c}$ & $42.70 \mathrm{c}$ & $60.54 \mathrm{~d}$ & $74.70 \mathrm{c}$ & $136.78 \mathrm{a}$ & $151.03 \mathrm{a}$ \\
\hline CNFC 11965 & $11.51 \mathrm{a}$ & $84.71 \mathrm{a}$ & 96.33 a & $110.59 \mathrm{a}$ & $119.20 \mathrm{a}$ & $131.19 \mathrm{a}$ & $128.26 \mathrm{~b}$ \\
\hline CVIII-2 & $12.30 \mathrm{a}$ & $15.96 \mathrm{~d}$ & $17.39 \mathrm{~d}$ & $22.12 \mathrm{f}$ & $30.16 \mathrm{e}$ & $81.08 \mathrm{~d}$ & $125.71 \mathrm{~b}$ \\
\hline CVIII-5 & $11.58 \mathrm{a}$ & $23.99 \mathrm{c}$ & $34.40 \mathrm{c}$ & $53.63 \mathrm{~d}$ & $69.79 \mathrm{c}$ & $110.83 \mathrm{~b}$ & $131.03 \mathrm{~b}$ \\
\hline EMB 14 & $10.66 \mathrm{a}$ & $56.30 \mathrm{~b}$ & $71.54 \mathrm{~b}$ & $88.97 \mathrm{~b}$ & $99.15 \mathrm{~b}$ & $117.04 \mathrm{~b}$ & $125.86 \mathrm{~b}$ \\
\hline EMB 4 & $11.49 \mathrm{a}$ & $44.88 \mathrm{~b}$ & $70.20 \mathrm{~b}$ & $88.60 \mathrm{~b}$ & $99.88 \mathrm{~b}$ & $120.76 \mathrm{~b}$ & $129.62 \mathrm{~b}$ \\
\hline EMB 9 & $11.70 \mathrm{a}$ & $18.81 \mathrm{~d}$ & $27.54 \mathrm{~d}$ & $40.36 \mathrm{e}$ & $59.15 \mathrm{~d}$ & $111.84 \mathrm{~b}$ & $130.49 \mathrm{~b}$ \\
\hline BRSMG MADREPÉROLA & $10.72 \mathrm{a}$ & $20.15 \mathrm{~d}$ & $28.44 \mathrm{~d}$ & $39.54 \mathrm{e}$ & $57.95 \mathrm{~d}$ & $120.07 \mathrm{~b}$ & $141.47 \mathrm{a}$ \\
\hline MAIV-15204 & $12.65 \mathrm{a}$ & $20.13 \mathrm{~d}$ & $24.88 \mathrm{~d}$ & $33.92 \mathrm{e}$ & $47.17 \mathrm{~d}$ & $98.43 \mathrm{c}$ & $124.93 \mathrm{~b}$ \\
\hline MAIV-18259 & $10.85 \mathrm{a}$ & $49.49 \mathrm{~b}$ & $60.74 \mathrm{~b}$ & $69.69 \mathrm{c}$ & $78.77 \mathrm{c}$ & $104.41 \mathrm{c}$ & $127.24 \mathrm{~b}$ \\
\hline MAIV-18524 & $11.32 \mathrm{a}$ & $34.33 \mathrm{c}$ & $43.40 \mathrm{c}$ & $56.03 \mathrm{~d}$ & $69.36 \mathrm{c}$ & $110.00 \mathrm{~b}$ & $128.52 \mathrm{~b}$ \\
\hline BRSMG MAJESTOSO & $8.53 \mathrm{a}$ & $12.14 \mathrm{~d}$ & $18.75 \mathrm{~d}$ & $31.70 \mathrm{e}$ & $48.15 \mathrm{~d}$ & $107.08 \mathrm{c}$ & $118.90 \mathrm{~b}$ \\
\hline P-18163 & $10.97 \mathrm{a}$ & $15.30 \mathrm{~d}$ & $18.27 \mathrm{~d}$ & $24.10 \mathrm{f}$ & $35.57 \mathrm{e}$ & $99.21 \mathrm{c}$ & $128.31 \mathrm{~b}$ \\
\hline PÉROLA & $11.19 \mathrm{a}$ & $14.76 \mathrm{~d}$ & $20.03 \mathrm{~d}$ & $29.89 \mathrm{e}$ & $45.32 \mathrm{~d}$ & $116.28 \mathrm{~b}$ & $138.61 \mathrm{a}$ \\
\hline RCII-219 & $11.73 \mathrm{a}$ & $32.71 \mathrm{c}$ & $42.71 \mathrm{c}$ & $55.23 \mathrm{~d}$ & $69.23 \mathrm{c}$ & $104.07 \mathrm{c}$ & $125.81 \mathrm{~b}$ \\
\hline BRSMG TALISMÃ & $11.42 \mathrm{a}$ & $20.02 \mathrm{~d}$ & $37.09 \mathrm{c}$ & $59.47 \mathrm{~d}$ & $77.04 \mathrm{c}$ & $115.98 \mathrm{~b}$ & $132.40 \mathrm{~b}$ \\
\hline VC-17 & $11.08 \mathrm{a}$ & $22.91 \mathrm{c}$ & $36.89 \mathrm{c}$ & $56.95 \mathrm{~d}$ & $76.18 \mathrm{c}$ & $117.19 \mathrm{~b}$ & $133.45 \mathrm{~b}$ \\
\hline VC-18 & $11.35 \mathrm{a}$ & $24.58 \mathrm{c}$ & $48.45 \mathrm{c}$ & $74.67 \mathrm{c}$ & $94.88 \mathrm{~b}$ & $126.63 \mathrm{a}$ & $132.93 \mathrm{~b}$ \\
\hline VC-19 & $11.32 \mathrm{a}$ & $18.51 \mathrm{~d}$ & $33.90 \mathrm{c}$ & $57.65 \mathrm{~d}$ & $81.19 \mathrm{c}$ & $119.57 \mathrm{~b}$ & $125.18 \mathrm{~b}$ \\
\hline VC-20 & $11.12 \mathrm{a}$ & $13.57 \mathrm{~d}$ & $15.88 \mathrm{~d}$ & $24.45 \mathrm{f}$ & $30.56 \mathrm{e}$ & $90.33 \mathrm{~d}$ & $123.57 \mathrm{~b}$ \\
\hline VC-21 & $11.52 \mathrm{a}$ & $14.63 \mathrm{~d}$ & $20.30 \mathrm{~d}$ & $33.16 \mathrm{e}$ & $57.08 \mathrm{~d}$ & $129.92 \mathrm{a}$ & $140.11 \mathrm{a}$ \\
\hline VC-22 & $11.74 \mathrm{a}$ & $15.07 \mathrm{~d}$ & $19.51 \mathrm{~d}$ & $32.53 \mathrm{e}$ & $54.94 \mathrm{~d}$ & $121.20 \mathrm{~b}$ & $130.45 \mathrm{~b}$ \\
\hline VC-23 & $10.90 \mathrm{a}$ & $15.62 \mathrm{~d}$ & $18.30 \mathrm{~d}$ & $22.65 \mathrm{f}$ & $27.49 \mathrm{e}$ & $79.57 \mathrm{~d}$ & $126.74 \mathrm{~b}$ \\
\hline CV $(\%)$ & 13.13 & & & & & & \\
\hline
\end{tabular}

Means followed by the same letter in a column are not significantly different (Scott-Knott test, $\mathrm{p}<0.05$ ).

$\mathrm{CV}=$ coefficient of variation. 
Hydration capacity at 1 and 2 hours was highest in genotype CNFC 11965, followed by CNFC 10432, EMB 14, EMB 4, and MAIV-18259, whereas HC was highest in genotype CNFC 11965 at 3 and 4 h, followed by CNFC 10432, EMB 14, and EMB 9. Additionally, $\mathrm{HC}$ at $8 \mathrm{~h}$ was significantly higher in genotypes CNFC 10763, CNFC 11965, CNFC 10432, VC-18, and VC-21 than in the remaining carioca cultivars. Conversely, $\mathrm{HC}$ at $24 \mathrm{~h}$ was highest in genotypes CNFC 10763, BRSMG Madrepérola, Pérola, and VC-21 (Table 3).

Line CNFC 11965 had the highest $\mathrm{HC}$ at 1, 2, 3, 4 , and $8 \mathrm{~h}$ (Table 3), suggesting that, due to its lack of hard seeds it displayed a high $\mathrm{HC}$ and required shorter cooking times. Some studies have found an association between higher $\mathrm{HC}$ and shorter cooking times (PÉREZ HERRERA et al., 2002;
RODRIGUES et al., 2005), while others have not (CARBONELL et al., 2003; DALLA CORTE et al., 2003).

The low HC of line CVIII-2, P-18163, VC20 , and VC-23 may be related to low seed coat permeability. In fact, according to Pujola et al. (2007), differences in hydration capacity among cultivars may be associated with differences in seed coat hardness (fewer intracellular spaces), cotyledon adherence (calcium pectate deposition in the middle lamella), elasticity, porosity, and colloidal properties across seeds from different cultivars. Regression analysis showed that hydration capacity increased with soaking time in a sigmoid manner across genotypes (Figure 1). The equation coefficients for each genotype are shown in Table 4.

Table 4. Sigmoid logistic regression coefficients for the relationship between soaking time (hours) and hydration capacity (\%) in seeds from 25 carioca bean genotypes; $a$ : maximum water absorption; $b$ : slope of the hydration capacity response; and $x_{0}$ : time to $50 \%$ soaking.

\begin{tabular}{|c|c|c|c|c|}
\hline GENOTYPE & $a$ & $b$ & $\mathbf{x}_{0}$ & $\mathbf{R}^{2}$ \\
\hline BRSMG MADREPÉROLA & $141.7546^{* *}$ & $1.9421^{* *}$ & $4.7273^{* *}$ & 0.99 \\
\hline BRSMG MAJESTOSO & $119.4258^{* *}$ & $1.6137^{* *}$ & $4.6208^{* *}$ & 0.99 \\
\hline PÉROLA & $139.5742^{* *}$ & $1.8174^{* *}$ & $5.2386^{* *}$ & 0.99 \\
\hline BRSMG TALISMÃ & $127.7623^{* *}$ & $1.5430^{* *}$ & $3.3666^{* *}$ & 0.99 \\
\hline CVIII-2 & $126.2538^{* *}$ & $2.5497^{* *}$ & $6.6483^{* *}$ & 0.99 \\
\hline CVIII-5 & $128.0357^{* *}$ & $1.8990^{* *}$ & $3.7818^{* *}$ & 0.99 \\
\hline EMB4 & $123.9323^{* *}$ & $1.1912^{* *}$ & $1.8763^{* *}$ & 0.97 \\
\hline EMB9 & $130.1377^{* *}$ & $1.9128^{* *}$ & $4.4487^{*}$ & 0.99 \\
\hline EMB14 & $119.6222^{* *}$ & $1.1905^{*}$ & $1.6191^{* *}$ & 0.95 \\
\hline CNFC 10408 & $132.5153^{* *}$ & $2.1079^{* *}$ & $4.7888^{* *}$ & 0.99 \\
\hline CNFC 10432 & $128.7843^{* *}$ & $1.2471^{*}$ & $1.6893^{* *}$ & 0.95 \\
\hline CNFC 10763 & $150.9606^{* *}$ & $1.8398^{* *}$ & $3.8751^{* *}$ & 0.99 \\
\hline CNFC 11965 & $119.7252^{* *}$ & $0.4494^{\mathrm{ns}}$ & $0.7480^{*}$ & 0.93 \\
\hline MAIV-15204 & $125.3357^{* *}$ & $2.2865^{* *}$ & $5.1260^{* *}$ & 0.99 \\
\hline MAIV-18259 & $120.3653^{* *}$ & $2.0511^{*}$ & $2.4466^{*}$ & 0.93 \\
\hline MAIV-18524 & $126.8112^{* *}$ & $2.1460^{* *}$ & $3.5647^{* *}$ & 0.98 \\
\hline P-18163 & $129.1852^{* *}$ & $2.0283^{* *}$ & $5.7476^{* *}$ & 0.99 \\
\hline RCII-219 & $123.0621^{* *}$ & $2.2023^{* *}$ & $3.5473^{* *}$ & 0.98 \\
\hline VC-17 & $129.8503^{* *}$ & $1.6445^{* *}$ & $3.4904^{* *}$ & 0.99 \\
\hline VC-18 & $130.4532^{* *}$ & $1.2247^{* *}$ & $2.7058^{* *}$ & 0.99 \\
\hline VC-19 & $124.0024^{* *}$ & $1.2922^{* *}$ & $3.1998^{* *}$ & 0.99 \\
\hline VC-20 & $124.2426^{* *}$ & $2.1472^{* *}$ & $6.0503^{* *}$ & 0.99 \\
\hline VC-21 & $141.5782^{* *}$ & $1.5109^{* *}$ & $4.6132^{* *}$ & 0.99 \\
\hline VC-22 & $131.9523^{* *}$ & $1.5438^{* *}$ & $4.5480^{* *}$ & 0.99 \\
\hline VC-23 & $127.3012^{* *}$ & $2.5889^{* *}$ & $6.8256^{* *}$ & 0.99 \\
\hline
\end{tabular}

${ }^{\mathrm{ns}}$ non-significant; ${ }^{*} \mathrm{P}<0.05 ;{ }^{* *} \mathrm{P}<0.01$. 
Lines CNFC 11965, EMB4, EMB14, and CNFC 10432 had both the shortest time to $50 \%$ soaking and cooking time (Tables 2 and 4), whereas VC-23, VC-20, and CVIII-2 had the longest times to $50 \%$ soaking (Table 4). Soaking rate is related to seed characteristics, including chemical composition and seed coat permeability (ALBUQUERQUE et al., 2009). Line VC-23 had the longest time to $50 \%$ soaking and the highest percentage of hard seeds (Tables 2 and 4). These results suggest that this genotype may have a less permeable seed coat, which may have caused slower water uptake and resulted in the high percentage of hard seeds.

\section{Conclusions}

Seed shape and constriction of genotypes EMB14, CNFC 10432, CNFC 10408, EMB4, P-18163, Pérola and BRSMG Madrepérola conformed to commercial standards.

Genotypes MAIV-18259, VC-20, VC-23, RCII219, CVIII-2, EMB4, MAIV-15204, CVIII-5, and BRSMG Majestoso had 1000-seed weight above $230 \mathrm{~g}$, conforming to the commercial standard for the "carioca" bean group.

Most genotypes had no hard seeds.

Lines CNFC 10408, MAIV-18259 and P-18163 displayed the highest soluble solid contents.

Twenty of the genotypes had cooking time better than the commercial standard, with the lowest cooking times found for lines EMB 9, EMB 4, MAIV-18524, CNFC 11965, VC-17 and CNFC 10432.

Lines CNFC 11965, EMB4, EMB14 and CNFC 10432 have the lowest soaking time.

\section{Acknowledgments}

We thank Universidade Federal de Viçosa (UFV) for providing the seeds and Universidade Estadual de Montes Claros (Unimontes) for logistical support;
FAPEMIG, Capes, and CNPq for scholarships, and Banco do Nordeste do Brasil (BNB) for financial support.

\section{References}

ABREU, A de F. B.; CARNEIRO, J. E. de S.; RAMALHO, M. A. P.; MELO, L. C.; PAULA JÚNIOR, TRAZILBO, J. de; PEREIRA FILHO, I. A.; MARTINS, M.; PEREIRA, H. S.; CARNEIRO, P. C. S.; DEL GIÚDICE, M. P.; VIEIRA, R. F.; TEIXEIRA, H.; DEL PELOSO, M. J.; FARIA, L. C. de.; SANTOS, J. B. dos; COSTA, J. G. C. da; MOREIRA, J. A. A.; WENDLAND, A. BRSMG Madréperola: cultivar de feijão tipo Carioca com escurecimento tardio dos grãos. Santo Antônio de Goiás: EMBRAPA, 2011. 4 p. (Comunicado técnico, 200).

ABREU, A. de F. B.; RAMALHO, M.A. P.; CARNEIRO, J. E. de S.; PELOSO, M. J. D.; PAULA JUNIOR, T. J. de; FARIA, L. C. de; MELO, L. C.; BARROS, E. G. de; MOREIRA, M. A.; PEREIRA FILHO, I. A.; MARTINS, M.; SANTOS, J. B. dos; RAVA, C. A.; COSTA, J. G. C. da; SARTORATO, A. BRSMG Majestoso: another common bean cultivar of carioca grain type for the state of Minas Gerais. Crop Breeding and Applied Biotechnology, Londrina, v. 7, n. 4, p. 403-405, 2007.

ALBUQUERQUE， K. S.; GUIMARÃES， R. M.; ALMEIDA, I. F. de; CLEMENTE, A. da C. O. S. Alterações fisiológicas e bioquímicas durante a embebição de sementes de sucupira-preta (Bowdichia virgilioides Kunth). Revista Brasileira de Sementes, Londrina, v. 31, n. 1, p. 12-19, 2009.

BASSINELLO, P. Z.; COBUCCI, R. de M. A.; ULHÔA, V. G.; MELO, L. C.; DEL PELOSO, M. J. Aceitabilidade de três cultivares de feijoeiro comum. Santo Antônio de Goiás: Embrapa Arroz e Feijão, 2003. 6 p. (Comunicado técnico, 66).

BERTOLDO, J. G.; COIMBRA, J. L. M.; GUIDOLIN, A. F.; ROCHA, F. da. Tempo de cocção de grãos de feijão em função de doses de fósforo no plantio e do tempo de armazenamento. Biotemas, Florianópolis, v. 22, n. 1, p. 39-47, 2009.

BORDIN, L. C.; COELHO, C. M. M.; SOUZA, C. A. de; ZILIO, M. Diversidade genética para a padronização do tempo e percentual de hidratação preliminar ao teste de cocção de grãos de feijão. Ciência e Tecnologia de Alimentos, Campinas, v. 30, n. 4, p. 890-896, 2010.

BRASIL. Ministério da Agricultura, Pecuária e Abastecimento - MAPA. Anexo IV. Requisitos mínimos 
para determinação do valor de cultivo e uso de feijão (Phaseolus vulgaris), para a inscrição no registro nacional de cultivares - RCN. Brasília: MAPA, 2006. 8 p. Disponível em: <http://www.cisoja.com.br/downloads/ legislacao/anexo_PT_294_4.pdf>. Acesso em: 16 jun. 2014.

CARBONELl, S. A. M.; CARVALHO, C. R. L.; AZEVEDO FILHO, J. A. de; SARTORI, J. A. Qualidade tecnológica de grãos de genótipos de feijoeiro cultivados em diferentes ambientes. Bragantia, Campinas, v. 62, n. 3, p. 369-379, 2003.

CARBONELL, S. A. M.; CHIORATO, A. F.; GONÇALVES, J. G. R.; PERINA, E. F.; CARVALHO, C. R. L. Tamanho de grão comercial em cultivares de feijoeiro. Ciência Rural, Santa Maria, v. 40, n. 10, p. 2067-2073, 2010.

COSTA, G. R.; RAMALHO, M. A. P.; ABREU, A. F. B. Variabilidade para absorção de água nos grãos de feijão do germoplasma da UFLA. Ciência e Agrotecnologia, Lavras, v. 25, n. 4, p. 1017-1021, 2001.

COSTA, J. G. C.; CABRERA, J. D. C.; FARIA, L. C.; WENDLAND, A.; DEL PELOSO, M. J.; PEREIRA, H. S.; MELO, L. C. Cultivares. Santo Antônio de Goiás: EMBRAPA ARROZ E FEIJÃO, 2015. Disponível em: $<$ http://www.agencia.cnptia.embrapa.br/gestor/feijao/ arvore/CONTAG01_26_243200313234.html>. Acesso em: 22 jul. 2015.

DALLA CORTE, A.; MODA-CIRINO, V.; SCHOLZ, M. B. da S.; DESTRO, D. Environment effect on grain quality in early common bean cultivars and lines. Crop Breeding and Applied Biotechnology, Londrina, v. 3, n. 3, p. 193-202, sept. 2003.

\section{EMPRESA BRASILEIRA DE PESQUISA} AGROPECUÁRIA - EMBRAPA Arroz e feijão. Dados conjunturais da produção de feijão (Phaseolus vulgaris L.) e caupi (Vigna unguiculata L.) no Brasil (1985 a 2013): área, produção e rendimento. Santo Antonio de Goiás: Embrapa Arroz e Feijão, 2014. Disponível em: $<$ http://www.cnpaf.embrapa.br/socioeconomia/index. htm>. Acesso em: 22 jul. 2015.

GARCIA-VELA, L. A.; STANLEY, D. W. Water-holding capacity in hard-to-cook bean (Phaseolus vulgaris L.): effect of ph and ionic strength. Journal of Food Science, Chicago, v. 54, n. 4, p. 1080-1081, 1989.

LEMOS, L. B.; OLIVEIRA, R. S. de; PALOMINO, E. C.; SILVA, T. R. B. da. Características agronômicas e tecnológicas de genótipos de feijão do grupo comercial carioca. Pesquisa Agropecuária Brasileira, Brasília, v. 39, n. 4, p. 319-326, abr. 2004.
MELO, C. L. P.; ALVAREZ, R. de C. F.; ARF, O.; CORREA, A. M.; PEREIRA, H. S.; MELO, L. C.; FARIA, L. C. de. BRS Notável: nova cultivar de feijoeirocomum semiprecoce do grupo carioca para Mato Grosso do Sul. Dourados: Embrapa Agropecuária Oeste, 2012. 4 p. (Comunicado técnico, 179).

MELO, L. C.; LEMES, G. de. C.; PELOSO, M. J. D.; FARIA, L. C. de; COSTA, J. G. C.; RAVA, C. A.; DIAZ, J. L. C.; ABREU, A. de F. B.; CARVALHO, H. W. L. de; TEIXEIRA, M. G.; WARWICK, D. R. N.; PEREIRA FILHO, I. A.; ZIMMERMANN, F. J. P. Estimativas de parâmetros genéticos, estabilidade e adaptabilidade no programa de melhoramento do feijoeiro comum da embrapa arroz e feijão. Santo Antônio de Goiás: Embrapa Arroz e Feijão. 2005. 31 p. (Boletim de Pesquisa e Desenvolvimento, 13).

NASAR-ABBAS, S. M.; PLUMMER, J. A.; SIDDIQUE, K. H. M.; WHITE, P.; HARRIS, D.; DODS, K. Cooking quality of faba bean after storage at high temperature and the role of lignins and other phenolics in bean hardening. LWT - Food Science and Technology, London, v. 41, n. 7, p. 1260-1267, 2008.

OLIVEIRA, D. P.; VIEIRA, N. M. B.; SOUZA, H. C.; MORAIS, A. R. de; PEREIRA, J.; ANDRADE, M. J. B. de. Qualidade tecnológica de grãos de cultivares de feijão-comum na safra das águas. Semina: Ciências Agrárias, Londrina, v. 33, n. 5, p. 1831-1838, 2012.

OLIVEIRA, V. R.; RIBEIRO, N. D. R.; JOST, E.; COLPO, E.; POERSCH, N. L. Perfil sensorial de cultivares de feijão sob diferentes tempos de cozimento. Alimentos e Nutrição, Araraquara, v. 24, n. 2, p. 145-152, 2013.

PEREIRA, H. S.; COSTA, A. F.; MELO, L. C.; DEL PELOSO, M. J.; FARIA, L. C.; WENDLAND, A. Interação entre genótipos de feijoeiro e ambientes no Estado de Pernambuco: estabilidade, estratificação ambiental e decomposição da interação. Semina: Ciências Agrárias, Londrina, v. 34, n. 6, p. 2603-2614, 2013.

PÉREZ HERRERA, P.; ESQUIVEL, G.; ROSALES SERNA, R.; ACOSTA-GALlEGOS, J. A. Caracterización física, culinaria y nutricional de frijol del altiplano subhúmedo de México. Archivos Latino Americanos de Nutrición, Caracas, v. 52, n. 2, p. 172180, 2002. Suplemento 2.

PERINA, E. F.; CARVALHO, C. R. L.; CHIORATO, A. F.; GONÇALVES, J. G. R.; CARBONELL, S. A. M. Avaliação de estabilidade e adaptabilidade de genótipos de feijoeiro (Phaseolus vulgaris L.) baseada na análise multivariada da performance genotípica. Ciência e Agrotecnologia, Lavras, v. 34, n. 2, p. 398-406, 2010. 
PROCTOR, J. R.; WATTS, B. M. Development of a modified Mattson bean cooker procedure based on sensory panel cookability evaluation. Canadian Institute of Food Science and Technology Journal, Apple Hill, v. 20, n. 1, p. 9-14, 1987.

PUERTA ROMERO, J. Variedades de judia cultivadas en España. Madri: Ministério da Agricultura, 1961. 798 p. (Monografias, 11).

PUJOLA, M.; FARRERAS, A.; CASANAS, F. Protein and starch content of raw, soaked and cooked beans (Phaseolus vulgaris L.). Food Chemistry, London, v. 102, n. 4, p. 1034-1041, 2007.

RAMALHO, M. A. P.; ABREU, A. F. B. Cultivares. In: VIEIRA, C.; PAULA JUNIOR, T. J.; BORÉM, A. (Ed.). Feijão. 2. ed. Viçosa, MG: Editora UFV, 2006. p. 415436.

RAMÍREZ-CÁRDENAS, L.; LEONEL, A. J.; COSTA, N. M. B. Efeito do processamento doméstico sobre o teor de nutrientes e de fatores antinutricionais de diferentes cultivares de feijão comum. Ciência e Tecnologia de Alimentos, Campinas, v. 28, n. 1, p. 200-213, 2008.
RIBEIRO,N.D.;RODRIGUES,J.deA.;CARGNELUTTI FILHO, A.; POERSCH, N. L.; TRETIN, M.; ROSA, S. $\mathrm{S}$. Efeito de períodos de semeadura e das condições de armazenamento sobre a qualidade de grãos de feijão para o cozimento. Bragantia, Campinas, v. 66, n. 1, p. 157163, 2007.

RIBEIRO, N. D.; SILVA, S. M.; GARCIA, D. C.; HOFFMANN JÚNIOR, L. Variabilidade genética para absorção de água em grãos de feijão. Pesquisa Agropecuária Gaúcha, Porto Alegre, v. 9, n. 1-2, p. 7783, 2003.

RODRIGUES, J. A.; RIBEIRO, N. D.; LONDERO, P. M. G.; CARGNELUTTI FILHO, A.; GARCIA, D. C. Correlação entre absorção de água e tempo de cozimento de cultivares de feijão. Ciência Rural, Santa Maria, v. 35, n. 1, p. 209-214, 2005.

ZIMMERMANN, L. de O. G.; COELHO, S. R. M.; CHRIST, D.; NÓBREGA, L. H. P. Alterações da qualidade tecnológica de marcas comerciais de feijão dos grupos cores e preto. Semina: Ciências Agrárias, Londrina, v. 30, n. 3, p. 619-628, 2009. 
